\title{
PROGRESS IN VEGETABLE PROTEINS ISOLATION TECHNIQUES: A REVIEW
}

\author{
Miroslav S. Hadnađev, Tamara R. Dapčević Hadnađev*, Milica M. Pojić, Bojana M. Šarić, Aleksandra \\ Č. Mišan, Pavle T. Jovanov, Marijana B. Sakač \\ University of Novi Sad, Institute of Food Technology, 21000 Novi Sad, \\ Bulevar cara Lazara 1, Serbia
}

\author{
${ }^{*}$ Corresponding author: \\ Phone: +381214853624 \\ Fax: +38121450725 \\ E-mail address: tamara.dapcevic@fins.uns.ac.rs
}

\begin{abstract}
Novel vegetable proteins, like those extracted from abundant raw materials (grass) or agri-food by-products and waste streams (oilseed meals), are expected to be used as replacers for animal-derived proteins, due to higher production efficiency, reduced life cycle environmental impact and possibility to meet consumers' dietary or cultural preferences. Although having a versatile functionality (emulsifying, foaming, gelling, texturizing agents), application of proteins is limited since their properties highly depend on their structure and composition, environmental factors $(\mathrm{pH}$, ionic strength, presence of other micro- and macro-molecules in food matrices) and isolation method and conditions.

The objective of this article is to review the current techniques used to isolate the proteins from vegetable raw materials and comment on the influence of extraction method and conditions $(\mathrm{pH}$, ionic strength, extraction media temperature, extraction time, etc.) on protein properties (yield, purity, appearance, solubility, denaturation degree, emulsification efficiency, etc.). The utilization of novel technologies such as ultrasound assisted extraction, electro-activation technique and approaches (enzyme-assisted extraction) to improve protein extraction yield or functionality was also discussed.
\end{abstract}

Key words: protein isolates, alkaline extraction, isoelectric precipitation, micellization, novel technologies

\section{INTRODUCTION}

Although animal proteins have a competitive advantage over plant-based proteins in terms of their nutritional and functional properties, protein ingredient market is intensively seeking for alternative, underutilized sources of concentrated plant proteins in order to satisfy the demands of consumers with different ethnic, religious, dietary and moral preferences associated with consumption of animal-based products. There are numerous reasons for the increased global demand for novel, sustainable sources of proteins which are also of high nutritional value. According to Food and Agriculture Organization of the United Nations (FAO) in 2050 an increase in world human population up to 9 billion is expected. Moreover, a consumption of animal proteins has been continuously increasing which affects gas emission from cattle breeding and thus represents an ecological issue (Spiegel et al., 2013). On the other hand, in both underdeveloped and developing countries population is faced with proteinenergy malnutrition (PEM), which is quite often among small children as well as in the elderly population. Moreover, popula- 
rity of so-called "protein diets" has been also increasing as well as the demand for high protein food products.

Plant sources of proteins that are already widely consumed are the ones obtained from soy, wheat, peas and potatoes. Oilseed meals, by-products obtained after oil extraction, legume seeds and green plants represent excellent alternative protein sources (Karaca et al., 2011; RodríguezAmbriz et al., 2005). In order to exploit protein sources with low carbon footprint, higher production sustainability and lower production costs, the possibility to isolate proteins from canola, flax, hemp seed meal, rice bran, chickpea, sugar beet leaves, fababeans, lemna (water lentil), etc. was investigated (Papalamprou et al., 2009; Wanasundara and Shahidi, 1996; $\mathrm{Xu}$ and Diosady, 2000). Moreover, according to Stegeman et al. (2010) raw materials that are currently used for feed and biofuel products such are rapeseed, algae, grass, duckweed as well as some byproducts obtained from agricultural processing and other waste materials could be used as good sources of proteins. However, the major issue of these socalled "novel proteins" is their safety aspect concerning the occurrence of antinutritional factors, contaminants, allergens and other substances which are present or could be formed during the processing that might have negative effect on human health.

Utilization of different plant protein isolates is mainly based on their versatility in the functional properties (solubility, viscosity, foam formation, emulsification, water and oil retention capacity etc.). Namely, their functional properties may originate from intrinsic factors such are protein composition and conformation, different environmental factors as well as the method of protein isolation (Fernández-Quintela et al., 1997).

Protein isolates are mostly obtained by solubilizing the protein rich source in an environment where the $\mathrm{pH}$ is far from the isoelectric point, followed by concentration with the aid of precipitation in an environment where the $\mathrm{pH}$ is close to the isoelectric point of the solubilized proteins. According to available literature data, iso- lation technique based on isoelectric protein precipitation in most of the cases results in coloured proteins due to coextracted chlorophylls and polyphenols which are very often of unpleasant and bitter taste that is undesirable from the technological and consumers point of view (Xu and Diosady, 2002). Another approach is to achieve protein solubilisation using saline solutions followed by protein precipitation due to salt removal through ultrafiltration and diafiltration membranes. The protein produced in this way has a micellar structure before being dried, with preserved native state (Arntfield et al., 1985).

The aim of this paper was to give an overview of protein isolation techniques and the effects of extraction conditions on the physicochemical and functional properties of the obtained protein isolates. The role of novel processing technologies and application of non-conventional approaches in protein isolation was also discussed.

\section{PROTEIN ISOLATION TECHNIQUES}

The most widely used procedures to prepare protein isolates from vegetable sources are presented in Figure 1. Alkaline extraction/isoelectric precipitation technique comprises alkaline solubilisation of the proteins, removal of the insoluble material by centrifugation, protein precipitation at $\mathrm{pH}$ which corresponds to isoelectric point and collection of precipitated protein by centrifugation. On the contrary, micellization involves protein extraction with salt solution, centrifugation to remove insoluble material, precipitation from a salt extract by ultrafiltration, diafiltration membranes or dilution in cold water, followed by protein recovery by centrifugation (Arntfield et al., 1985; Paredes-López and Ordorica-Falomir, 1986).

Both techniques could be applied using different extraction and concentration conditions. The extraction conditions employyed to isolate vegetable proteins as well as protein precipitation/purification conditions are summarized in Table 1.

Some authors have combined the effect of $\mathrm{NaCl}$ concentration with $\mathrm{pH}$ in order to 
increase the efficiency of protein extraction. Moure et al. (2001) extracted 55\% to $60 \%$ of the proteins from Rosa rubiginosa seeds using $0.5 \mathrm{M} \mathrm{NaCl}$ solution and $\mathrm{pH}$ 11. When subjecting the cowpeas $(10 \%$ (w/v) solid/solution ratio) to a $0.15 \mathrm{M} \mathrm{NaCl}$ solution adjusted to $\mathrm{pH} 9.9$, during $2 \mathrm{~h}$ at $35{ }^{\circ} \mathrm{C}$, Mune et al. (2008) obtained protein yields higher than $87 \%$.

Studies which have used alkaline extraction/isoelectric precipitation technique for protein isolation have mostly reviled that extraction conditions at $\mathrm{pH}$ values 10.0 and higher result in increased yield of extracted proteins (Gerzhova et al., 2016). Mwasaru et al. (1999) concluded that increase in extraction $\mathrm{pH}$ from 8.5 to 12.5 increased the pigeon pea and cowpea protein extractability from 35.1 to $58.1 \%$ and 36.4 to $53.5 \%$, respectively. According to Arntfield et al. (1990), highly alkaline conditions during protein extrac-tion led to extensive protein denaturation. Therefore, a compromise has to be found between higher protein yields and extent of their denaturation. Similarly, rise in temperature and/or extraction time also contributes to better extractability of proteins. However, increase in temperature might also cause protein thermal denaturation and precipitation. Therefore, room or slightly higher temperatures are commonly advisable for protein extraction. According to different literature data extraction time is usually set between 10 and 60 min with constant stirring and at $5-15 \%(\mathrm{w} / \mathrm{v})$ solid/solution ratio (Rodrigues et al., 2012).

Concerning micellization technique, increased ionic strength is often related to higher protein recoverability. Paredes-López and Ordorica-Falomir (1986) have increased safflower protein recoverability more than two times by increasing sodium chloride concentration from $0.1 \mathrm{M}$ to 1.2 $M$. They have also shown that decrease in extraction $\mathrm{pH}$ from 7.0 to 5.8 , at the same ionic strength, had slight influence on the increase in protein yield.

Depending on the extraction technique employed, the subsequent processes of protein concentration involve ultrafiltration, diafiltration membranes or simple precipitation at $\mathrm{pH}$ value close to isoelectric value of extracted solubilized proteins (Table 1). The concentrated protein solution is afterward bring to powder state using freeze drying, vacuum drying or spray drying techniques.

Isoelectric precipitation technique more frequently leads to higher yields of extracted proteins than the micellization methods, which is documented for different protein isolates such are safflower ( $\mathrm{Pa}$ redes-López and Ordorica-Falomir, 1986), pigeon pea, cowpea (Mwasaru et al., 1999) and Lupinus campestris (RodríguezAmbriz et al., 2005).
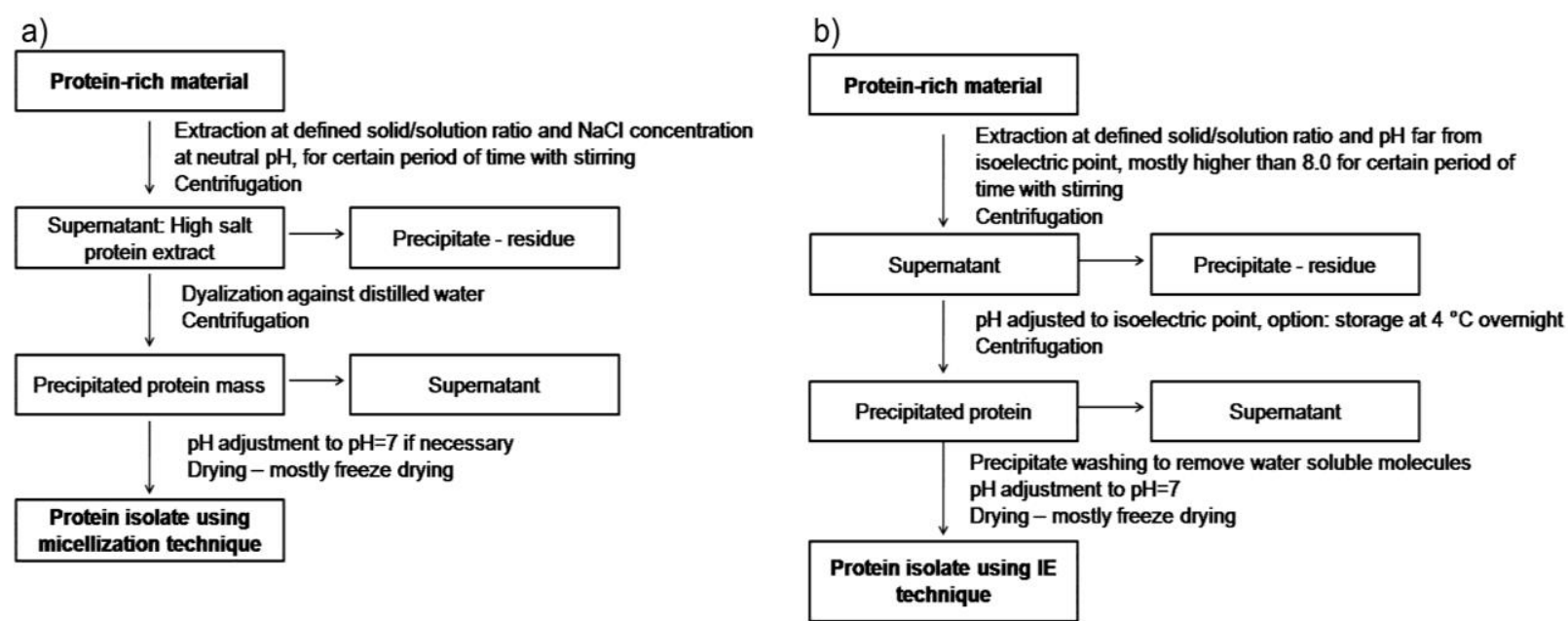

Figure 1. Protein isolation scheme using micellization technique (salt extraction) (a) and alkaline extraction/isoelectric precipitation (b) 


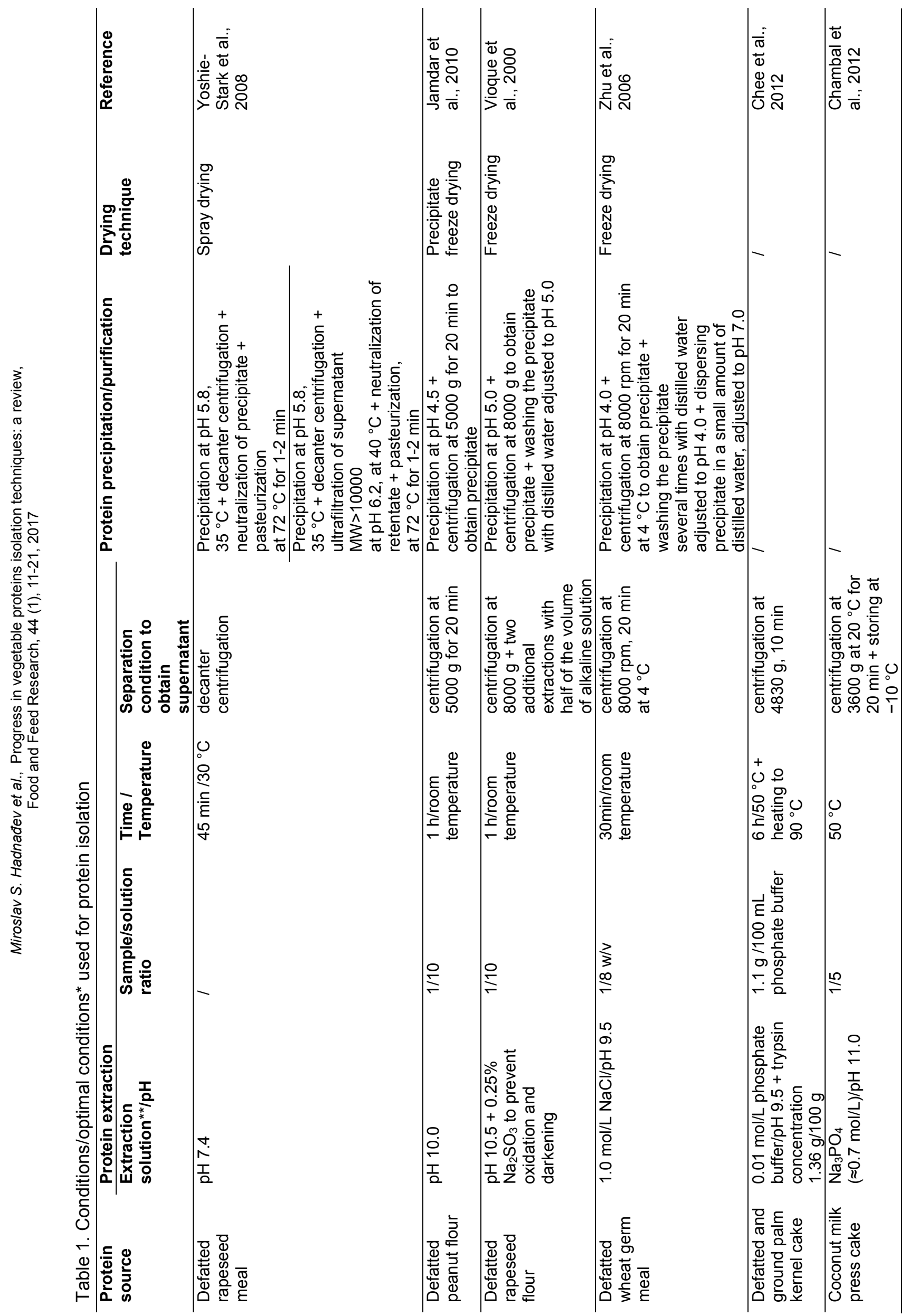




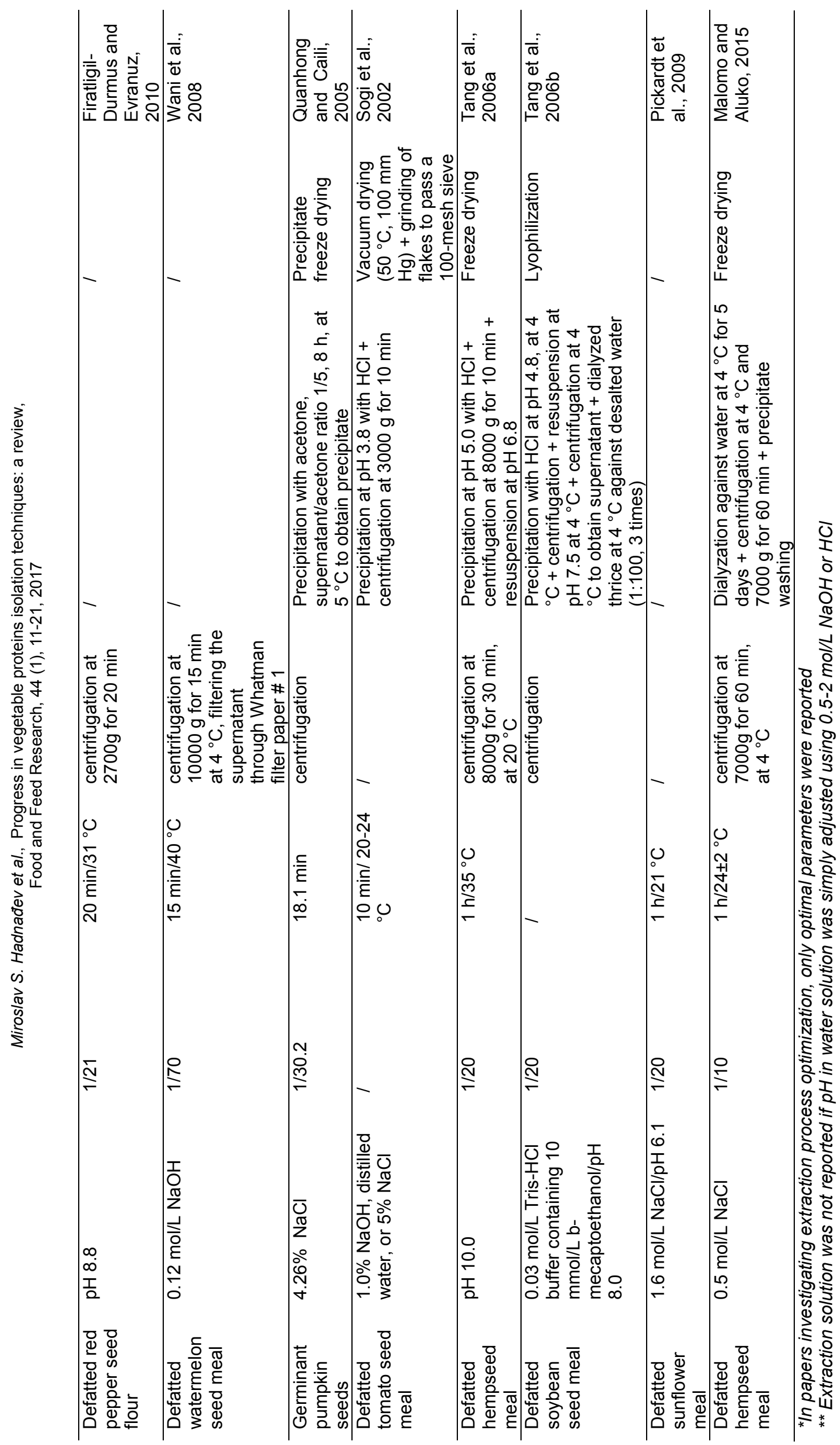


According to Rodríguez-Ambriz et al. (2005) this higher yield of extracted proteins using isoelectric precipitation technique is governed by higher selectivity of so-called "salting out" technique to one protein fraction (globulins) when compared to procedure involving alkaline extraction followed by precipitation at isoelectric point. Namely, during micellization procedure albumins remain in the supernatant after salt removal in the dialyses step, while globulins precipitate and can be collected by centrifugation (Malomo and Aluko, 2015).

However, according to Papalamprou et al. (2009) alkali extraction/isoelectric precipitation procedure also favours the extraction of globulin rather than albumin fraction. When proteins are recovered using isoelectric precipitation technique, albumins are eliminated during globulin fraction precipitation at the isoelectric point. Concerning the purity of extracted proteins, Mwasaru et al. (1999) noticed that protein isolates of pigeon pea seed obtained by micellization procedure were of higher purity in comparison to protein isolates derived by isoelectric precipitation technique.

Beside protein yield and purity, while choosing the isolation techniques, it is important to consider the one which will result in protein products characterised by reduced or eliminated undesirable compounds such are glucosinolates, phytates and erucic acid (Aherne et al., 1976; Badawy et al., 1994; Brand et al., 2007; Fenwick et al., 1983; Liener, 1994; Tripathi and Mishra, 2006) and targeted protein functionality for specific application.

\section{INFLUENCE OF ISOLATION METHOD ON PROTEIN FUNCTIONAL PRO- PERTIES}

Different extraction techniques and conditions $(\mathrm{pH}$ value, presence or absence of mono- and polyvalent salts, ionic strength of medium used for protein extraction, time, temperature, etc.) influence the protein functional properties. It is generally common that extraction techniques that involve long and high temperature conditions result in protein isolates of reduced nutritional quality. In alkaline extractable medium the series of undesirable reaction such are amino acid racemization, lysinoalanine formation, digestibility decrease and loss of essential amino acids can usually occur (Moure et al., 2006). According to $\mathrm{Xu}$ and Diosady (2002), under alkaline conditions polyphenols, that can be found in many plant materials, oxidize and subsequently can react with protein resulting in dark green or brown colour of extracted protein solutions. After the precipitation at isoelectric point and after several washing steps, the obtained colour cannot be removed from protein isolates. On the contrary, at alkaline conditions (above $\mathrm{pH}$ 10.0) the extraction of phytic acid is very low (Ghodsval et al., 2005; Tzeng et al., 1988; Tzeng et al., 1990). Micellization technique, which represents a milder extraction procedure, does not involve polyphenols oxidation, polymerization and co-extraction with protein as in the case of alkaline extracted protein isolates. Therefore, isolates obtained using micellization technique are usually of lighter colour.

Protein isolates obtained by processes of ultrafiltration are commonly of better functional properties in comparison to isolates obtained by alkaline extraction, especially in their emulsifying properties. Concerning the protein solubility, the advantage was given to micellization extraction procedure since this technique gave protein isolates of higher solubility in comparison to isolates obtained by isoelectric point procedure (Karaca et al., 2011; Krause et al., 2002; Paredes-López and Ordorica-Falomir, 1986). Besides the better solubility, interfacial activity was also higher for protein isolates obtained by micellization technique compared to isoelectric precipitation. However, water binding capacity was found to be higher for flaxseed protein isolates obtained by isoelectric point procedure in comparison to the same isolates derived by micellization technique (Krause et al., 2002). According to Krause et al. (2002) and Papalamprou et al. (2009) micellization technique resulted in protein isolates of more preserved native protein structure in comparison to isoelectric precipitated ones. Generally, the latter one results in limited denaturation of extracted 
proteins followed by protein molecules hydrophobic interactions which can lead to development of insoluble protein aggregates. Thermal analysis (DSC) showed that micellar protein isolates were characterized with significantly higher enthalpies (higher structural order) than the isolates obtained by isoelectric precipitation (Murray et al., 1985; Mwasaru et al., 1999; Paredes-López et al., 1991). This behaviour can be ascribed to partial denaturation of the protein isolates obtained by isoelectric precipitation technique in comparison to isolates obtained by micellization procedure. According to Murray et al. (1985) micellization extraction procedure involves milder extraction conditions compared to isoelectric precipitation conditions resulting in protein isolates with the least conformational and structural changes. Arntfield and Murray (1981) concluded that increase in the extraction $\mathrm{pH}$ value resulted in decrease in enthalpy values, meaning that more denaturated protein isolates were obtained.

Protein isolates obtained by isoelectric precipitation technique are characterized by higher content of phytic acid in comparison to isolates produced by micellization procedure (Krause et al., 2002). According to Krause et al. (2002) conditions of $\mathrm{pH}$ below isoelectric point of extracted proteins are favourable for insoluble phytic acid-protein complexes formation resulting in lower solubility of protein isolates produced by isoelectric precipitation rather than it is for the isolates obtained by micellization procedure.

According to electrophoretic measurements both isolation procedures gave the same fraction of proteins (Dapčević Hadnađev et al., 2016; Krause et al., 2002). Rodríguez-Ambriz et al. (2005) confirmed that certain mobility differences of protein isolates obtained with different extraction techniques could be related to protein structure changes, composition as well as to protein and residual salt interactions in protein isolates. SDS-PAGE analysis of canola proteins showed that salt addition significantly increased proteins solubility (Gerzhova et al., 2016).

However, various post-isolation procedures based on different chemical, phy- sical and enzymatic modifications can further improve functional properties of protein isolates in terms of solubility, emulsification and foam formation capacity and stability, as well as nutritional value, such as formation of bioactive peptides. It was already shown that protein isolate hydrolysis with different proteases improved its antioxidant properties (Cumby et al., 2008; Hadnađev et al., 2016; Jamdar et al., 2010; Li et al., 2008).

\section{APPLICATION OF NOVEL TECHNO- LOGIES FOR PROTEIN EXTRACTION}

In order to increase the yield, improve protein functionality and/or increase production sustainability different novel technologies and approaches are applied for proteins production. Their influence on protein yield is summarized in Table 2.

Ultrasound assisted extraction was employed by Zhu at al. (2009) to isolate proteins from defatted wheat germ flour with the aid of reverse micellar solution. They showed that, under optimized conditions, the extraction efficiency of defatted wheat germ proteins can increase from $37 \%$ to $57 \%$.

Implementation of enzymatic assisted protein extraction was also proposed as a method for improving protein extraction yield. This method usually involves the addition of different enzymes (protease, cellulose etc.) in order to increase the amount of extracted proteins and to lower protein damage during the extraction (Eapen et al., 1966). According to Rosenthal et al. (2001) enzyme assisted protein extraction could have positive impact on soy protein extraction yield when thermally treated flour was used. While the addition of cellulase did not have positive effect on extracted protein content, the protease assisted extraction was found to be promising technique when performing extraction of oil and protein hydrolysate in a single step process.

Ho et al. (2007) proposed the extraction procedure based on pressurized low polarity water as an alternative to solvent extraction, which usually acquires the use of solvents, long extraction time, intensive labour procedures and increase in waste generation. 
Table 2. Influence on novel technologies and approaches on protein recoverability

\begin{tabular}{|c|c|c|c|}
\hline $\begin{array}{l}\text { Novel isolation } \\
\text { approach/technique }\end{array}$ & Protein source & $\begin{array}{l}\text { Improvement in } \\
\text { comparison to } \\
\text { convectional technique }\end{array}$ & Reference \\
\hline $\begin{array}{l}\text { Ultrasound assisted } \\
\text { extraction with the aid of } \\
\text { reverse micellar solution }\end{array}$ & Defatted wheat germ flour & $\begin{array}{l}\text { Extraction efficiency } \\
\text { increased from } 37 \% \text { to } \\
57 \%\end{array}$ & Zhu at al., 2009 \\
\hline $\begin{array}{l}\text { Ultrasound assisted } \\
\text { extraction }\end{array}$ & Olive kernels & $\begin{array}{l}\text { Extraction efficiency } \\
\text { increased more than two } \\
\text { times }\end{array}$ & Roselló-Soto et al., 2015 \\
\hline $\begin{array}{l}\text { Enzymatic (protease) } \\
\text { assisted extraction }\end{array}$ & $\begin{array}{l}\text { Soy flour - heat treated or } \\
\text { with large particle size }\end{array}$ & $\begin{array}{l}\text { Yield increased from } \\
27.8 \% \text { to } 66.2 \%\end{array}$ & Rosenthal et al., 2001 \\
\hline $\begin{array}{l}\text { Pressurized low polarity } \\
\text { water extraction }\end{array}$ & Defatted flaxseed meal & $\begin{array}{l}\text { Optimal yield (225.6 } \\
\mathrm{mg} / \mathrm{g}) \text { was obtained at } \mathrm{pH} \\
9.0,160^{\circ} \mathrm{C} \text { and } 210 \mathrm{~mL} / \mathrm{g} \\
\mathrm{S} / \mathrm{S} \text { in comparison to } \\
\text { treatment involving } \mathrm{pH} \\
4.0,190^{\circ} \mathrm{C} \text { and } 210 \mathrm{~mL} / \mathrm{g} \\
\mathrm{S} / \mathrm{S} \text { which resulted in } 17.4 \\
\mathrm{mg} / \mathrm{g} \text { protein }\end{array}$ & Ho et al., 2007 \\
\hline $\begin{array}{l}\text { Electro-activated } \\
\text { technique }\end{array}$ & Defatted canola meal & $\begin{array}{l}\text { Protein extractability } \\
\text { increased from } 31.18 \% \text { to } \\
34.32 \%\end{array}$ & Gerzhova et al., 2015a \\
\hline \multirow[t]{2}{*}{$\begin{array}{l}\text { Pulsed-electric-field } \\
\text { technique }\end{array}$} & $\begin{array}{l}\text { Nanochloropsis and } \\
\text { Chlorella }\end{array}$ & $\begin{array}{l}\text { Not competitive with } \\
\text { mechanical disintegration } \\
\text { in terms of protein release }\end{array}$ & $\begin{array}{r}\text { Coustets and Teissié, } \\
2016\end{array}$ \\
\hline & Olive kernels & $\begin{array}{l}\text { Not efficient at defined } \\
\text { extraction parameters }\end{array}$ & Roselló-Soto et al., 2015 \\
\hline $\begin{array}{l}\text { High voltage electrical } \\
\text { discharges }\end{array}$ & Olive kernels & $\begin{array}{l}\text { Extraction efficiency } \\
\text { increased two times }\end{array}$ & Roselló-Soto et al., 2015 \\
\hline
\end{tabular}

They obtained flaxseed protein optimal yield at $\mathrm{pH} 9.0,160{ }^{\circ} \mathrm{C}$ and $210 \mathrm{~mL} / \mathrm{g}$ solvent to solid.

Electro-activated technique was also proposed as an alternative, non-invasive extraction method. According to this method, electric field was employed in order to produce alkaline water solutions which are claimed to have good extractive properties. According to Gerzhova et al. (2015a), the use of electro-activation technique resulted in increased amount of extracted proteins in comparison to conventional alkaline extraction/isoelectric precipitation. The same group of authors also concluded that there were no significant differences in terms of solubility, surface hydrophobicity, water absorption as well as oil absorption capacity between the protein isolates obtained by conventional alkaline extraction method and electro- activated method (Gerzhova et al., 2015b). Coustets and Teissié (2016) proposed pulsed-electric-field technique - procedure which involves electro-permeabilization of cell walls and/or membranes for protein extraction from Nanochloropsis and Chlorella.

Roselló-Soto et al. (2015) compared high voltage electrical discharges (HVED), pulsed electric field (PEF) and ultrasound (US) as pretreatments before extraction of protein and phenolic compounds from olive kernels. They found that HVED treatment was more effective than ultrasound and pulsed electric field in terms of energy input and effective treatment time. While PEF did not influence the increase in content of proteins, US and HVED treatments significantly improved amount of extracted proteins, which increase with the increase in input energy. 


\section{ACKNOWLEDGEMENTS}

This paper is a result of the research within the project "Techno-functionality of proteins isolated from alternative plantbased raw materials produced in the Province of Vojvodina" (Project No. 114-4512379/2016-03) financed by the Provincial Secretariat for Higher Education and Scientific Research, Republic of Serbia.

\section{REFERENCES}

1. Aherne, F.X., Bowland, J.P., Hardin, R.T., Christian, R.G. (1976). Performance of myocardial and blood seral changes in pigs fed diets containing high or low erucic acid rapeseed oils. Canadian Journal of Animal Science, 56 (2), 275-284.

2. Arntfield, S.D., Murray, E.D. (1981). The influence of processing parameters on food protein functionality I. Differential scanning calorimetry as an indicator of protein denaturation. Canadian Institute of Food Science and Technology Journal, 14 (4), 289-294.

3. Arntfield, S.D., Ismond, M.A.H., Murray, E.D. (1985). The fate of antinutritional factors during the preparation of a fababean protein isolate using a micellization technique. Canadian Institute of Food Science and Technology Journal, 18 (2), 137-143.

4. Arntfield, S.D., Ismond, M.A.H., and Murray, E.D. (1990). Thermal analysis of food proteins in relation to processing effects. In Thermal Analysis of Foods. Eds. V.R. Harwalkar, C.-Y. Ma, Elsevier, London, pp. 51-91.

5. Badawy, I.H., Atta, B., Ahmed, W.M. (1994). Biochemical and toxicological studies on the effect of high and low erucic acid rapeseed oil on rats. Molecular Nutrition \& Food Research, 38 (4), 402-411.

6. Brand, T.S., Smith, N., Hoffman, L.C. (2007). Anti-nutritional factors in canola produced in the Western and Southern Cape areas of South Africa. South African Journal of Animal Science, 37 (1), 45-50.

7. Chambal, B., Bergenståhl, B., Dejmek, P. (2012). Edible proteins from coconut milk press cake; one step alkaline extraction and characterization by electrophoresis and mass spectrometry. Food Research International, 47 (2), 146-151.

8. Chee, K.L., Ling, H.K., Ayob, M.K. (2012). Optimization of trypsin-assisted extraction, physico-chemical characterization, nutritional qualities and functionalities of palm kernel cake protein. LWT-Food Science and Technology, 46 (2), 419-427.

9. Coustets, M., Teissié, J. (2016). The Use of Pulsed Electric Fields for Protein Extraction from Nanochloropsis and Chlorella. $1^{\text {st }}$ World Congress on Electroporation and Pulsed Electric Fields in Biology, Medicine and Food \&
Environmental Technologies, Portorož, Slovenia, IFMBE Proceedings, pp. 405-408.

10. Cumby, N., Zhong, Y., Naczk, M., Shahidi, F. (2008). Antioxidant activity and water-holding capacity of canola protein hydrolysates. Food Chemistry, 109 (1), 144-148.

11. Dapčević Hadnađev, T., Hadnađev, M., Lazaridou, A., Moschakis, T., Biliaderis, C. (2016). Physicochemical properties of hemp (Cannabis sativa L.) protein isolates: effects of isolation technique and conditions. International Congress FoodTech 2016: III International Congress "Food Technology, Quality and Safety", and XVII International Symposium "Feed Technology", Novi Sad 2016, Serbia, Book of Abstracts, p. 200, Novi Sad, Serbia.

12. Eapen, K.E., Kalbag, S.S., Subrahmanyan, V. (1966). Key operations in the wet-rendering of peanut for the isolation of protein, oil and starch. Journal of the American Oil Chemists Society, 43 (10), 585-589.

13. Fenwick, G.R., Heaney, R.K., Mullin, W.J., VanEtten, C.H. (1983). Glucosinolates and their breakdown products in food and food plants. CRC Critical Reviews in Food Science and Nutrition, 18 (2), 123-201.

14. Fernández-Quintela, A., Macarulla, M.T., Del Barrio, A.S., Martínez, J.A. (1997). Composition and functional properties of protein isolates obtained from commercial legumes grown in northern Spain. Plant Foods for Human Nutrition, 51 (4), 331-341.

15. Firatligil-Durmus, E., Evranuz, O. (2010). Response surface methodology for protein extraction optimization of red pepper seed (Capsicum frutescens). LWT-Food Science and Technology, 43 (2), 226-231.

16. Gerzhova, A., Mondor, M., Benali, M., Aider, M. (2015a). A comparative study between the electro-activation technique and conventional extraction method on the extractability, composition and physicochemical properties of canola protein concentrates and isolates. Food Bioscience, 11, 56-71.

17. Gerzhova, A., Mondor, M., Benali, M., Aider, M. (2015b). Study of the functional properties of canola protein concentrates and isolates extracted by electro-activated solutions as noninvasive extraction method. Food Bioscience, $12,128-138$

18. Gerzhova, A., Mondor, M., Benali, M., Aider, M. (2016). Study of total dry matter and protein extraction from canola meal as affected by the $\mathrm{pH}$, salt addition and use of zeta-potential/turbidimetry analysis to optimize the extraction conditions. Food Chemistry, 201, 243-252.

19. Ghodsvali, A., Khodaparast, M.H., Vosoughi, M., Diosady, L.L. (2005). Preparation of canola protein materials using membrane technology and evaluation of meals functional properties. Food Research International, 38 (2), 223-231.

20. Hadnađev, M., Hadnađev-Dapčević, T., Dizdar, M., Nedeljković, N., Pojić, M. (2016). Antioxidant activity of hemp protein hydrolysates: effect of protease type and hydrolysis degree, 18th World congress of food 
science and technology - lufost 2016, Dublin, Ireland, Book of Abstracts, p. 1519.

21. Ho, C.H., Cacace, J.E., Mazza, G. (2007). Extraction of lignans, proteins and carbohydrates from flaxseed meal with pressurized low polarity water. LWT-Food Science and Technology, 40 (9), 1637-1647.

22. Jamdar, S.N., Rajalakshmi, V., Pednekar, M.D., Juan, F., Yardi, V., Sharma, A. (2010). Influence of degree of hydrolysis on functional properties, antioxidant activity and ACE inhibitory activity of peanut protein hydrolysate. Food Chemistry, 121 (1), 178-184.

23. Karaca, A.C., Low, N., Nickerson, M. (2011). Emulsifying properties of canola and flaxseed protein isolates produced by isoelectric precipitation and salt extraction. Food Research International, 44 (9), 2991-2998.

24. Krause, J.P., Schultz, M., Dudek, S. (2002). Effect of extraction conditions on composition, surface activity and rheological properties of protein isolates from flaxseed (Linum usitativissimum L). Journal of the Science of Food and Agriculture, 82 (9), 970-976.

25. Li, Y., Jiang, B., Zhang, T., Mu, W., Liu, J. (2008). Antioxidant and free radical-scavenging activities of chickpea protein hydrolysate (CPH). Food Chemistry, 106 (2), 444-450.

26. Liener, I.E. (1994). Implications of antinutritional components in soybean foods. Critical Reviews in Food Science \& Nutrition, 34 (1), 31-67.

27. Malomo, S.A. and Aluko, R.E. (2015). A comparative study of the structural and functional properties of isolated hemp seed (Cannabis sativa L.) albumin and globulin fractions. Food Hydrocolloids, 43, 743-752.

28. Moure, A., Sineiro, J., Dominguez, H. (2001). Extraction and functionality of membraneconcentrated protein from defatted Rosa rubiginosa seeds. Food Chemistry, 74, 327339.

29. Moure, A., Sineiro, J., Domínguez, H., Parajó, J.C. (2006). Functionality of oilseed protein products: a review. Food Research International, 39 (9), 945-963.

30. Mune, M.A.M., Minka, S.R., Mbome, I.L. (2008). Response surface methodology for optimisation of protein concentrate preparation from cowpea [Vigna unguiculata (L.) Walp]. Food Chemistry, 110, 735-741.

31. Murray, E.D., Arntfield, S.D., Ismond, M.A.H. (1985). The influence of processing parameters on food protein functionality II. Factors affecting thermal properties as analyzed by differential scanning calorimetry. Canadian Institute of Food Science and Technology Journal, 18 (2), 158-162.

32. Mwasaru, M.A., Muhammad, K., Bakar, J., Man, Y.B.C. (1999). Effects of isolation technique and conditions on the extractability, physicochemical and functional properties of pigeonpea (Cajanus cajan) and cowpea (Vigna unguiculata) protein isolates. I. Physico-chemical properties. Food Chemistry, 67 (4), 435443.
33. Paredes-López, O. and Ordorica-Falomir, C. (1986). Production of safflower protein isolates: Composition, yield and protein quality. Journal of the Science of Food and Agriculture, 37 (11), 1097-1103.

34. Paredes-López, O., Ordorica-Falomir, C., Olivares-Vázquez, M.R. (1991). Chickpea protein isolates: physicochemical, functional and nutritional characterization. Journal of Food Science, 56 (3), 726-729.

35. Papalamprou, E.M., Doxastakis, G.I., Biliaderis, C.G., Kiosseoglou, V. (2009). Influence of preparation methods on physicochemical and gelation properties of chickpea protein isolates. Food Hydrocolloids, 23 (2), 337-343.

36. Pickardt, C., Neidhart, S., Griesbach, C., Dube, M., Knauf, U., Kammerer, D.R., Carle, R. (2009). Optimisation of mild-acidic protein extraction from defatted sunflower (Helianthus annuus L.) meal. Food Hydrocolloids, 23 (7), 1966-1973.

37. Quanhong, L., Caili, F. (2005). Application of response surface methodology for extraction optimization of germinant pumpkin seeds protein. Food Chemistry, 92 (4), 701-706.

38. Rodrigues, I.M., Coelho, J.F., Carvalho, M.G.V. (2012). Isolation and valorisation of vegetable proteins from oilseed plants: Methods, limitations and potential. Journal of Food Engineering, 109 (3), 337-346.

39. Rodríguez-Ambriz, S.L., Martínez-Ayala, A.L., Millán, F., Davila-Ortiz, G. (2005). Composition and functional properties of Lupinus campestris protein isolates. Plant Foods for Human Nutrition, 60 (3), 99-107.

40. Roselló-Soto, E., Barba, F.J., Parniakov, O., Galanakis, C.M., Lebovka, N., Grimi, N., Vorobiev E. (2015). High voltage electrical discharges, pulsed electric field, and ultrasound assisted extraction of protein and phenolic compounds from olive kernel. Food and Bioprocess Technology, 8 (4), 885-894.

41. Rosenthal, A., Pyle, D.L., Niranjan, K., Gilmour, S., Trinca, L. (2001). Combined effect of operational variables and enzyme activity on aqueous enzymatic extraction of oil and protein from soybean. Enzyme and Microbial Technology, 28 (6), 499-509.

42. Sogi, D.S., Garg, S.K., Bawa, A.S. (2002). Functional properties of seed meals and protein concentrates from tomato-processing waste. Journal of Food Science, 67 (8), 29973001.

43. Spiegel, V.D.M., Noordam, M.Y., Fels-Klerx, H.J. (2013). Safety of novel protein sources (insects, microalgae, seaweed, duckweed, and rapeseed) and legislative aspects for their application in food and feed production. Comprehensive Reviews in Food Science and Food Safety, 12 (6), 662-678.

44. Stegeman, D., Janssen, A.M., Helsper, J.P. F.G., Van der Meer, I.M., Van Kernebeek, H.R.J. (2010). Technologie en grondstoffen voor vleesvervangers en hoogwaardige eiwitten (No. 1179). Wageningen UR Food \& Biobased Research. 
45. Tang, C.H., Ten, Z., Wang, X.S., Yang, X.Q. (2006a). Physicochemical and functional properties of hemp (Cannabis sativa L.) protein isolate. Journal of Agricultural and Food Chemistry, 54 (23), 8945-8950.

46. Tang, C.H., Wu, H., Yu, H.P., Li, L., Chen, Z., Yang, X.Q. (2006b). Coagulation and gelation of soy protein isolates induced by microbial transglutaminase. Journal of Food Biochemistry, 30 (1), 35-55.

47. Tripathi, M.K. and Mishra, A.S. (2007). Glucosinolates in animal nutrition: A review. Animal Feed Science and Technology, 132 (1), 1-27.

48. Tzeng, Y.M., Diosady, L.L., Rubin, L.J. (1988). Preparation of rapeseed protein isolates using ultrafiltration, precipitation and diafiltration. Canadian Institute of Food Science and Technology Journal, 21 (4), 419-424.

49. Tzeng, Y. M., Diosady, L.L., Rubin, L.J. (1990). Production of canola protein materials by alkaline extraction, precipitation, and membrane processing. Journal of Food Science, 55 (4), 1147-1151.

50. Vioque, J., Sánchez-Vioque, R., Clemente, A., Pedroche, J., Millán, F. (2000). Partially hydrolyzed rapeseed protein isolates with improved functional properties. Journal of the American Oil Chemists' Society, 77 (4), 447-450.
51. Wanasundara, P.K. J.P.D., Shahidi, F. (1996). Optimization of Hexametaphosphate-Assisted Extraction of Flaxseed Proteins Using Response Surface Methodology. Journal of Food Science, 61 (3), 604-607.

52. Wani, A.A., Kaur, D., Ahmed, I., Sogi, D.S. (2008). Extraction optimization of watermelon seed protein using response surface methodology. LWT-Food Science and Technology, 41 (8), 1514-1520.

53. Xu, L. and Diosady, L.L. (2002). Removal of phenolic compounds in the production of highquality canola protein isolates. Food Research International, 35 (1), 23-30.

54. Yoshie-Stark, Y. Wada,Y., Wäsche, A. (2008). Chemical composition, functional properties, and bioactivities of rapeseed protein isolates. Food Chemistry, 107, 32-39.

55. Zhu, K.X., Sun, X.H., Zhou, H.M. (2009). Optimization of ultrasound-assisted extraction of defatted wheat germ proteins by reverse micelles. Journal of Cereal Science, 50 (2), 266-271.

56. Zhu, K., Zhou, H., Qian, H. (2006). Antioxidant and free radical-scavenging activities of wheat germ protein hydrolysates (WGPH) prepared with alcalase. Process Biochemistry, 41 (6), 1296-1302.

\title{
ПРЕГЛЕД РАЗВОЈА ТЕХНИКА ИЗОЛОВАЊА БИЉНИХ ПРОТЕИНА
}

\author{
Мирослав С. Хаднађев, Тамара Р. Дапчевић Хаднађев*, Милица М. Појић, Бојана М. Шарић, \\ Александра Ч. Мишан, Павле Т. Јованов, Маријана Б. Сакач
}

Универзитет у Новом Саду, Научни институт за прехрамбене технологије у Новом Саду, 21000 Нови Сад, Булевар цара Лазара 1, Србија

Сажетак: Нове врсте биљних протеина, као што су они изоловани из широко распрострањених извора (трава) или агро-индустријских споредних производа и ефлуената (погаче уљарица), ће према очекивањима заменити протеине анималног порекла, из разлога као што су: већа ефрикасност производње, смањен утицај на животни циклус околине и могућност задовољења навика у исхрани и културолошких разлика потрошача. Иако поседују разнолику функционалност (емулгујуће особине, способност образовања пене, гелова, текстуре производа), примена протеина је ограничена услед чињенице да су њихове особине веома зависне од њихове структуре и састава, утицаја спољашње средине $(\mathrm{pH}$, јонска јачина раствора, присуство микро- и макро-молекула у прехрамбеном систему), као и метода и услова изоловања.

Циљ овог рада је да да преглед тренутних техника изоловања протеина из биљних сировина, као и утицаја метода и услова $(\mathrm{pH}$, јонска јачина раствора, температура раствора за екстракцију, време екстракције и др.) изоловања на особине протеина (принос, степен чистоће, изглед, растворљивост, степен денатурације, ефикасност емулговања, и сл.). Примена нових технологија, као што су екстракција уз примену ултразвука, техника електро-активације, као и приступа (екстракција уз помоћ ензима) у циљу побољшања приноса протеина или функционалности била је такође тема овог рада.

Кључне речи: изолат протеина, алкална екстракција, изоелектрична преципитација, мицелизација, нове технологије

Received: 10 March 2017 